\title{
EFEKTIVITAS VARIASI UMPAN PADA FLY TRAP DALAM PENGENDALIAN KEPADATAN LALAT
}

\author{
Shela Savitriani ${ }^{1}$, Nur Afni Maftukhah ${ }^{2 *}$
}

${ }^{1,2}$ STIKes Muhammadiyah Palembang, Sumatera Selatan, Indonesia

\section{Artikel Info :}

Received 7 Agustus 2020

Accepted 17 April 2021

Available online 30 April

2021

Editor: Prayudhy Yushananta

Keyword :

Flytrap, flies, shrimp, fish gill

Kata kunci :

Fly trap, lalat, udang, insang ikan

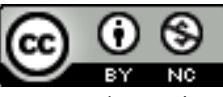

Ruwa Jurai: Jurnal

Kesehatan Lingkungan is

licensed under a Creative

Commons Attribution-

NonCommercial 4.0 International

License.

\begin{abstract}
Flies are the main vector of gastrointestinal infections, so it must control them. Flytraps are one of the fly control methods that are considered the few risk to environmental health. This study aims to determine the effectiveness of flytraps decoy variations in chikens farm. The study used a completely randomized design (CRD), during February-April 2019. Two types of bait (shrimp and fish gills) were used from traditional market waste and placed in the flytrap (size $50 \mathrm{~cm} \times 50 \mathrm{~cm} \times$ $50 \mathrm{~cm}$ ). All trapped flies were counted using a tally counter two times (every 60 minutes). Experiments were carried out with five replication for each type of bait. The results showed that the total number of flies caught using fish gill bait was more (363) than shrimp (317). In the first 60 minutes, shrimp bait attracts as many as 22.8 flies $(S D=1.3)$ and 40.6 fish $(S D=3.6)$ in the second 60 minutes. Gill bait of fish attracted 25.4 individuals $(S D=0.9)$, and 47.2 individuals (SD $=2.6$ ). The time variable shows the effect on the number of flies caught; it's related to decomposition time. The characteristics of fish gills high in water, protein, and blood are thought to cause interest in flies. The use of fly traps with fish gill bait is more effective than shrimp bait to apply it.
\end{abstract}

\begin{abstract}
Lalat merupakan vektor utama penyakit infeksi pencernaan, sehingga harus dikendalikan. Fly trap adalah salah satu metode pengendalian lalat yang dianggap paling kecil risikonya terhadap kesehatan lingkungan. Penelitian bertujuan mengetahui efektifitas variasi umpan pada fly trap di peternakan ayam. Penelitian menggunakan rancangan acak lengkap (RAL) yang dilaksanakan selama bulan Februari-April 2019. Dua jenis umpan (udang dan insang ikan) digunakan dari limbah pasar tradisional, dan diletakkan pada Fly trap (ukuran $50 \mathrm{~cm} \times 50 \mathrm{~cm} x$ $50 \mathrm{~cm}$ ). Seluruh lalat yang terperangkap dihitung menggunakan tally counter selama dua kali 60 menit Percobaan dilakukan dengan lima kali pengulangan pada setiap jenis umpan. Hasil penelitian mendapatkan jumlah total lalat yang terperangkap menggunakan umpan insang ikan lebih banyak (363 ekor) dibandingkan umpan udang (317 ekor). Pada 60 menit pertama, umpan udang mampu menarik lalat sebanyak 22,8 ekor $(S D=1,3)$, dan 40,6 ekor $(S D=3,6)$ pada 60 menit kedua. Umpan insang ikan menarik 25,4 ekor $(S D=0,9)$, dan 47,2 ekor $(S D=2,6)$. Variabel waktu menunjukkan pengaruh terhadap jumlah lalat yang terperangkap, berkaitan dengan waktu pembusukan. Karakteristik insang ikan yang tinggi kandungan air, protein, dan terdapat darah, diduga menjadi penyebab ketertarikan lalat. Penggunaan fly trap dengan umpan insang ikan lebih efektif dibandingkan umpan udang, sehingga dapat diaplikasikan dalam pengendalian lalat.
\end{abstract}

${ }^{* *}$ Corresponding author: Nur Afni Maftukhah

Prodi DIII Kesehatan Kesehatan Lingkungan STIKes Muhammadiyah Palembang, Sumatera Selatan

Jl. Jenderal Ahmad Yani, 13 Ulu, Kec. Seberang Ulu II, Kota Palembang, Sumatera Selatan 30262. Indonesia.

Email: afni.maftukhah@gmail.com

\section{PENDAHULUAN}

Diare adalah penyebab kematian utama pada anak-anak. Pada tahun 2017, diare menjadi penyebab sekitar 8\% kematian dari semua kematian anak balita di seluruh dunia. Artinya, sekitar 1.300 anak meninggal setiap hari akibat diare, dan sebagian besar kematian ada di Asia Selatan dan Afrika sub-Sahara (UNICEF, 2020). Diare merupakan penyebab morbiditas dan mortalitas yang serius, sekitar $2 \%$ dari semua episode diare berkembang menjadi penyakit 
parah dan kematian (Walker et al., 2013). Di Indonesia, prevalensi diare pada balita adalah $11 \%$ dan merupakan penyebab kematian kedua terbesar pada anak balita (Ministry of Health Indonesia, 2019). Intervensi yang telah dilakukan untuk menurunkan angka diare, mulai dari perbaikan gizi, suplementasi vitamin $A$, dan vaksin rotavirus, perilaku hidup bersih dan sehat, hingga perbaikan air bersih dan sanitasi (Adisasmito, 2007; Bhutta et al., 2013; Sanyaolu, Okorie, Marinkovic, Jaferi, \& Prakash, 2020; Ugboko, Nwinyi, Oranusi, \& Oyewale, 2020; UNICEF, 2020; Yushananta, Ahyanti, \& Hasan, 2018; Yushananta \& Usman, 2018).

Penularan diare dari feces melalui beberapa jalur lingkungan yang sering dikonsepkan sebagai 5F:Fluids, Fingers, Food, Fields, Flies (Pickering et al., 2018; Wateraid, 2019). Lalat merupakan vektor penyakit menular, terutama diare (Agtini, 2011; Emerson et al., 1999; Kusariana, 2013; Sucipto, 2011). Lalat memiliki kemampuan reproduksi yang cepat (siklus hidup sekitar 15 hari) dan suka hinggap di kotoran manusia dan hewan serta bahan yang sudah membusuk (Acharya, 2015; Attaullah et al., 2020; Budiman \& Suyono, 2011; Geden, 2012; Klauck et al., 2018). Kebiasaan mengeluarkan cairan perutnya selama makan juga menjadi penyebab pencemaran makanan (Palus, Sanam, \& Detha, 2016).

Pengendalian vektor dapat dilakukan dengan mengurangi populasi, menghilangkan tempat perindukan, mengurangi sumber daya tarik lalat, sehingga mencegah interaksi antara lalat dengan manusia melalui makanan dan peralatan makan (Chavasse, Blumenthal, \& Kolsky, 1994; Das et al., 2018; Pickering et al., 2018). Metode pengendalian adalah dengan cara fisik-mekanik, biologi, dan kimia. Saat ini, pengendalian kimia menggunakan insektisida menjadi pilihan yang paling banyak digunakan. Namun, cara kimia memberikan efek membahayakan bagi serangga non target, paparan terhadap manusia dan lingkungan, serta timbulnya resistensi pada lalat (Acharya, 2015; Anisah \& Sukesi, 2018; Attaullah et al., 2020; Geden, 2012; Klauck et al., 2018; Mosokuli, 2001; Yunianti Lapida, 2016).

Salah satu metode pengendalian lalat secara fisik-mekanik adalah menggunakan flytrap, yaitu perangkap lalat dewasa yang menggunakan umpan (atraktan) sebagai penarik (Putra, 2018).
Atraktan adalah bahan yang digunakan sebagai umpan agar lalat tertarik untuk hinggap. Beberapa penelitian telah melaporkan penggunaan berbagai umpan dengan hasil yang bervariasi, antara lain udang, ikan segar, fermentasi buah, fermentasi cabe, cairan gula (Fitriana \& Mulasari, 2021; Krisdiyanta \& Ariyani, 2018; Nadeak, Rwanda, \& Iskandar, 2017; Putra, 2018; Suraini, 2013). Penelitian bertujuan menilai efektivitas variasi umpan terhadap ketertarikan lalat. Jenis umpan yang digunakan adalah udang basah dan insang ikan yang diperoleh dari limbah pasar tradisional. Pengamatan dan perhitungan jumlah lalat hinggap (terperangkap) dilakukan selama 120 menit, dengan interval 60 menit. Penelitian dilakukan di salah satu peternakan ayam di Kecamatan Muara Enim, Kabupatan Muara Enim.

\section{BAHAN dan METODE}

Penelitian menggunakan rancangan acak lengkap (RAL) untuk mengetahui perbedaan jumlah tangkapan lalat menggunakan dua jenis umpan (udang dan insang ikan), dan dua satuan waktu pengamatan (60 menit pertama, dan 60 menit kedua). Penelitian dilaksanakan selama bulan Februari-April 2019, di peternakan ayam CV "X" Kecamatan Muara Enim, Kabupaten Muara Enim, Sumatera Selatan.

Dua jenis umpan disiapkan, yaitu udang basah dan insang ikan. Keseluruhan bahan diperoleh dari limbah pasar tradisonal Kecamatan Muara Enim, Kabupatan Muara Enim. Umpan diletakkan di dalam perangkap lalat (flytrap) berukuran $50 \mathrm{~cm} \times 50 \mathrm{~cm} \times 50 \mathrm{~cm}$, terbuat dari rangka kayu dengan dinding kawat kasa. Flytrap yang sudah diberi umpan (atraktan) diletakkan di dua tempat terpisah sejauh 10 meter dari kandang. Seluruh lalat yang terperangkap dihitung menggunakan tallycounter. Dilakukan dua kali perhitungan, yaitu 60 menit pertama dan 60 menit kedua. Sehingga setiap umpan digunakan untuk 120 menit pengamatan. Percobaan dilakukan dengan lima kali pengulangan pada setiap jenis umpan.

Data yang terkumpul diolah dan dianalisis menggunakan perangkat SPSS versi 24.0. Ukuran rerata (Mean) dan Standard Deviasi (SD) digunakan untuk menggambarkan jumlah lalat yang terperangkap berdasarkan jenis umpan dan waktu pengamatan. Uji T digunakan untuk 
menilai perbedaan jumlah lalat yang terperangkap berdasarkan jenis umpan dan waktu pengamatan.

\section{HASIL}

Hasil penelitian mendapatkan bahwa total lalat yang terperangkap menggunakan umpan udang selama 120 menit sebanyak 317 ekor, dan insang ikan sebanyak 363 ekor. Jika dikelompokkan berdasarkan jenis umpan dan waktu pengukuran, maka rerata jumlah lalat terperangkap dengan umpan udang pada 60 menit pertama sebanyak 22,8 ekor $(S D=1,3)$; dan 60 menit kedua sebanyak 40,6 ekor $(S D=3,6)$. Pada kelompok dengan umpan insang ikan, sebanyak 25,4 ekor $(S D=0,9)$; dan 47,2 ekor $(S D=2,6)$.

Tabel 1. Jumlah lalat terperangkap berdasarkan jenis umpan dan waktu

\begin{tabular}{|c|c|c|c|c|c|c|c|c|c|c|}
\hline \multirow{2}{*}{$\begin{array}{l}\text { Jenis } \\
\text { umpan }\end{array}$} & \multirow{2}{*}{ Waktu } & \multicolumn{5}{|c|}{ Replikasi } & \multirow{2}{*}{\multicolumn{2}{|c|}{ Jumlah }} & \multirow{2}{*}{ Mean } & \multirow{2}{*}{ SD } \\
\hline & & 1 & 2 & 3 & 4 & 5 & & & & \\
\hline \multirow[t]{2}{*}{ Udang } & $60^{\prime}$ pertama & 23 & 21 & 24 & 22 & 24 & \multirow{2}{*}{317} & 114 & 22,8 & 1,3 \\
\hline & 60" kedua & 44 & 36 & 44 & 38 & 41 & & 203 & 40,6 & 3,6 \\
\hline \multirow[t]{2}{*}{ Insang ikan } & $60^{\prime}$ pertama & 24 & 26 & 26 & 26 & 25 & \multirow{2}{*}{363} & 127 & 25,4 & 0,9 \\
\hline & $60 "$ kedua & 43 & 50 & 47 & 48 & 48 & & 236 & 47,2 & 2,6 \\
\hline
\end{tabular}

Replikasi=pengulangan, Mean=rerata, SD=Standard Deviasi

Tabel 2 menunjukkan perbedaan jumlah lalat terperangkap berdasarkan jenis umpan, serta jenis umpan dan waktu, menggunakan uji $\mathrm{T}$ (alpha $=0,05$ ). Hasil analisis statistik menunjukkan tidak terdapat perbedaan jumlah lalat terperangkap berdasarkan jenis umpan $(p=0,35)$. Rerata perbedaan kedua kelompok sebanyak 4,6 ekor. Gambar 1.a memperlihatkan perbandingan jumlah lalat terperangkap berdasarkan jenis umpan.

Pengujian perbedaan lalat terperangkap juga dilakukan berdasarkan jenis umpan pada setiap waktu pengukuran (Tabel 2). Pada 60 menit pertama, hasil statistik menunjukkan perbedaan jumlah lalat terperangkap berdasarkan jenis umpan $(p=0,006)$. Demikian pula pada 60 menit kedua, juga menunjukkan perbedaan yang signifikan $(p=0,01)$. Gambar 1.b memperlihatkan perbandingan jumlah lalat terperangkap berdasarkan waktu perhitungan pada masingmasing jenis umpan. Pada umpan udang, sebanyak 114 ekor lalat terperangkap pada 60 menit pertama, dan 203 ekor pada 60 menit kedua. Sedangkan dengan umpan insang ikan, sebanyak 127 ekor pada 60 menit pertama, dan 236 ekor pada 60 menit kedua.

Tabel 2. Perbedaan jumlah lalat terperangkap berdasarkan jenis umpan, dengan $T$-Test

\begin{tabular}{llllll}
\hline Variabel & Kelompok & $\mathrm{t}$ & $\mathrm{p}$-value & $\mathrm{MD}$ & $\mathrm{SE}$ \\
\hline Jenis umpan & - & 0,96 & 0,35 & 4,60 & 4,79 \\
60' pertama & Jenis umpan & 3.67 & 0,006 & 2,60 & 0,71 \\
$60^{\prime \prime}$ kedua & Jenis umpan & 3.34 & 0,01 & 6,60 & 1,97 \\
\hline
\end{tabular}

$\mathrm{MD}=$ Mean Difference, SE=Standard Eror, Alpha $=0,05$
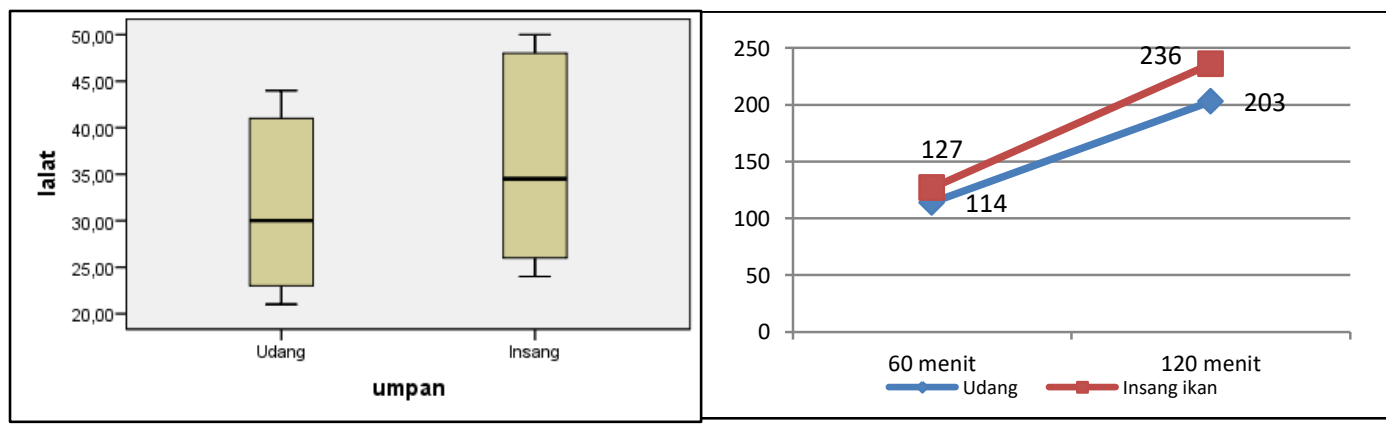

Gambar 1. Perbandingan jumlah lalat terperangkap berdasarkan umpan (a), dan waktu (b) 


\section{PEMBAHASAN}

Berdasarkan Tabel 1 terlihat bahwa jumlah lalat yang terperangkap dengan umpan insang ikan lebih banyak (363 ekor) dibandingkan udang (317 ekor). Namun secara statistik (Tabel 2) belum menunjukkan perbedaan yang bermakna $(p=0,35)$. Dilakukan pengelompokan waktu pengamatan berdasarkan jenis umpan (Tabel 2). Hasilnya menunjukkan perbedaan nyata jumlah lalat terperangkap berdasarkan jenis umpan, baik pada 60 pertama $(p=0,006)$ maupun pada 60 menit kedua $(p=0,01)$. Hasil ini menjelaskan bahwa variabel waktu mempengaruhi jumlah lalat terperangkap. Semakin lama waktu pengamatan, maka semakin banyak lalat yang terperangkap. Dari nilai MD dapat diketahui, bahwa umpan insang ikan lebih disukai dibandingkan udang.

Hasil penelitian ini sesuai dengan beberapa penelitian sebelumnya yang menyatakan bahwa umpan insang ikan lebih disukai oleh lalat, sehingga sangat efektif sebagai atraktan (Fitri, 2020; Saipin, Fadmi, \& Mauliyana, 2019; Tanjung, 2016). Umpan yang paling disukai lalat dari tiga jenis umpan yang digunakan, yaitu udang basah, insang ikan dan ampas tebu (Nelson et al., 2016). Insang merupakan organ utama respirasi yang berperan penting dalam proses osmoregulasi, keseimbangan ion dan sekresi nitrogen. Insang terdiri dari tiga bagian utama yaitu arcus branchialis, filamen branchialis, dan branchiospinalis. Arcus branchialis merupakan jalur pernapasan (arterierial) dan jalur arteriovenous yang berasal dari pembuluh darah filamen yang berhubungan langsung dengan respirasi dan sirkulasi (Faumi et al., 2020). Limbah insang ikan memiliki karakteristik yang tinggi kandungan air, terdapat kandungan darah, tinggi protein, serta berbau amis menyengat (Fahrizal \& Ratna, 2018).

Tingginya kandungan air umpan insang dibandingkan dengan umpan udang, diduga sebagai salah satu penarik lalat untuk hinggap. Lalat lebih menyukai bahan makanan berbentuk cair atau kandungan air yang tinggi. Pada bahan makanan kering, lalat akan mengeluarkan cairan dari perutnya untuk membasahi makanan (Nadeak et al., 2017; Putra, 2018; Suraini, 2013). Kebiasaan menghinggapi makanan dan mengeluarkan cairan dari perut merupakan mekanisme pencemaran makanan dan penularan penyakit (Putra, 2018).

Kandungan air yang tinggi menyebabkan ikan lebih mudah membusuk, dibandingkan udang. Semakin lama ikan dibiarkan dalam kondisi terbuka, maka semakin banyak mikroorganisme yang hadir untuk mempercepat proses pembusukan. Proses pembusukan yang terjadi pada ikan menimbulkan aroma menyengat (Saipin et al., 2019)

Terdapatnya darah pada insang ikan juga diduga sebagai penarik bagi lalat untuk hinggap. Darah merupakan bahan cair dengan kandungan protein yang tinggi. Protein merupakan makan yang sangat disukai lalat dan digunakan sebagai tempat meletakkan telurnya (Fahrizal \& Ratna, 2018; Leke, Widyastuti, Mandey, Najon, \& Laihad, 2015; Oktavia, Mangunwidjaja, Wibowo, \& Sunarti, 2012; Putra, 2018). Limbah perikanan biasanya berupa potongan kepala, insang, dan isi perut ikan yang masih terdapat darah, sehingga mudah mengalami pembusukan (Fahrizal \& Ratna, 2018; Leke et al., 2015). Degradasi protein oleh mikroorganisme akan menghasilkan gas hydrogen sulfida $\left(\mathrm{H}_{2} \mathrm{~S}\right)$ yang berbau busuk, dan mengundang lalat (Oktavia et al., 2012; Palus et al., 2016; Ristiati, Suryanti, \& Indrawan, 2018). Lalat memiliki indra penciuman yang sangat peka pada antena dan palpus, sehingga mampu mencium bau yang menguap dalam suhu kamar, dan bahan yang membusuk (Nadeak et al., 2017; Tanjung, 2016). Gas sulfida yang dihasilkan dari proses pembusukan merupakan penarik bagi lalat (Ristiati et al., 2018; Shane, Montrose, \& Harrington, 1985; Wang et al., 2015).

Hasil penelitian juga mendapatkan bahwa variabel waktu berpengaruh terhadap jumlah lalat yang terperangkap pada flytrap. Jumlah lalat yang terperangkap lebih tinggi pada 60 menit kedua dibandingkan 60 mneit pertama, pada setiap jenis umpan. Hasil ini menunjukkan bahwa lalat lebih suka pada bahan makanan yang membusuk. Bau busuk yang disebabkan oleh dekomposisi protein menghasilkan hidrogen sulfida, gugus thiol, dan amoniak (Oktavia et al., 2012; Palus et al., 2016; Ristiati et al., 2018). Gas akan menguap dan terperangkap oleh indra penciuman lalat (Nadeak et al., 2017; Tanjung, 2016). Lalat tertarik pada bau yang 
menyengat (Kaufman, Nunez, Geden, \& Scharf, 2010; Onyenwe, Okore, O, Ubiaru, \& Abel, 2016; Wahyudi, Hadi, \& Soviana, 2015).

Beberapa penelitian sebelumnya melaporkan bahwa umpan udang lebih disukai lalat (Fitriana \& Mulasari, 2021; Krisdiyanta \& Ariyani, 2018; Nadeak et al., 2017). Kandungan protein yang tinggi dan warna terang, merupakan variabel yang disukai lalat baik (Nadeak et al., 2017). Namun, penelitian Nadaek membandingkan penggunaan umpan udang dengan fermentasi cabai dan tomat busuk (Nadeak et al., 2017). Sedangkan pada dua penelitian lainnya menggunakan ikan segar (Fitriana \& Mulasari, 2021; Krisdiyanta \& Ariyani, 2018). Pada penelitian ini, umpan ikan yang digunakan adalah limbah insang ikan. Karakteristik insang ikan yang tinggi kandungan air, protein, dan terdapat darah, diduga sebagai penyebab tingginya ketertarikan lalat dibandingkan terhadap umpan udang.

\section{SIMPULAN}

Hasil penelitian mendapatkan jumlah total lalat yang terperangkap menggunakan umpan udang selama 120 menit sebanyak 317 ekor, dan insang ikan sebanyak 363 ekor. Pada 60 menit pertama, umpan udang mampu menarik 22,8 ekor $(S D=1,3)$ lalat, dan 40,6 ekor $(S D=3,6)$ pada 60 menit kedua. Umpan insang ikan menarik 25,4 ekor $(S D=0,9)$, dan 47,2 ekor $(S D=2,6)$. Walaupun terdapat deviasi jumlah tangkapan, namun hasil uji statistik belum menunjukkan perbedaan yang nyata. Perbedaan signifikan terdapat jumlah tangkapan lalat berdasarkan waktu. Karakteristik insang ikan yang tinggi kandungan air, protein, dan terdapat darah, diduga menjadi penyebab ketertarikan lalat. Penggunaan fly trap dengan umpan insang ikan lebih efektif dibandingkan umpan udang, sehingga dapat diaplikasikan dalam pengendalian lalat.

\section{DAFTAR PUSTAKA}

Acharya, N. (2015). House fly (Musca domestica L.) management in poultry production using fungal biopesticides. ProQuest Dissertations and Theses, (May), 185.

Adisasmito, W. (2007). Faktor Risiko Diare pada Bayi dan Balita di Indonesia. Jurnal Makara
Kesehatan, 11(1), 1-10.

Agtini, M. D. (2011). Morbiditas dan Mortalitas

Diare pada Balita di Indonesia Tahun 2000-2007. Ministry of Health, 2(2), 26-32.

Anisah, A., \& Sukesi, T. W. (2018). Uji Efektifitas Ekstrak Daun Sirih (Piper betle L) sebagai Larvasida Larva Lalat Rumah (Musca domestica). Jurnal Vektor Penyakit, 12(1), 39-46. https://doi.org/10.22435/vektorp.v12i1.283 Attaullah, Zahoor, M. K., Zahoor, M. A., Mubarik, M. S., Rizvi, H., Majeed, H. N., ... Qamer, S. (2020). Insecticidal, biological and biochemical response of Musca domestica (Diptera: Muscidae) to some indigenous weed plant extracts. Saudi Journal of Biological Sciences, 27(1), 106-116. https://doi.org/10.1016/j.sjbs.2019.05.009

Bhutta, Z. A., Das, J. K., Walker, N., Rizvi, A., Campbell, H., Rudan, I., \& Black, R. E. (2013). Interventions to address deaths from childhood pneumonia and diarrhoea equitably: what works and at what cost? The Lancet, 381(9875), 14171429. https://doi.org/10.1016/S01406736(13)60648-0

Budiman, \& Suyono. (2011). Ilmu kesehatan masyarakat: dalam konteks kesehatan lingkungan (M. Ester, Ed.). Jakarta: EGC.

Chavasse, D. C., Blumenthal, U., \& Kolsky, P. (1994). Fly control in prevention of diarrhoeal disease. The Lancet, 344(8931), 1231. https://doi.org/10.1016/S0140-6736(94)90547-9 Das, J. K., Hadi, Y. B., Salam, R. A., Hoda, M., Lassi, Z. S., \& Bhutta, Z. A. (2018). Fly control to prevent diarrhoea in children. Cochrane Database of Systematic Reviews, 2018(12). https://doi.org/10.1002/14651858.CD011654.pu b2

Emerson, P. M., Lindsay, S. W., Walraven, G. EL, Faal, H., Bøgh, C., Lowe, K., \& Bailey, R. L. (1999). Effect of fly control on trachoma and diar rhoea. The Lancet, 353(9162), 1401-1403. https://doi.org/10.1016/S0140-6736(98)09158-2 Fahrizal, A., \& Ratna, R. (2018). Pemanfaatan Limbah Pelelangan Ikan Jembatan Puri Di Kota Sorong Sebagai Bahan Pembuatan Tepung Ikan. Gorontalo Fisheries Journal, 1(2), 10. https://doi.org/10.32662/.v1i2.421

Faumi, R., Akmal, Y., Zulfahmi, I., Almuslim, U., Almuslim, J., Dua, M. G., ... Aceh, B. (2020). Perbandingan Secara Anatomi Insang Ikan Keureling ( Tor tambroides), Ikan Mas ( Cyprinus carpio ) dan Ikan Nila, (Oreochromis niloticus ). Jurnal Veteriner, 21(36), 234-246.

https://doi.org/10.19087/jveteriner.2020.21.2.23 
4

Fitri, A. (2020). Efektivitas Variasi Umpan Organik pada Eco-Friendly Fly Trap sebagai Upaya Penurunan Populasi Lalat di RPU Penggaron Kota Semarang. Universitas Negeri Semarang.

Fitriana, E., \& Mulasari, S. A. (2021). Efektifitas Variasi Umpan Pada Fly Trap Dalam Pengendalian Kepadatan Lalat Di Tempat Pembuangan Sementara (TPS) Jalan Andong Yogyakarta. Jurnal Kesehatan Lingkungan Indonesia, 20(1), 59-64. https://doi.org/10.14710/jkli.20.1.59-64

Geden, C. J. (2012). Status of biopesticides for control of house flies. Journal of Biopesticides, 5(SUPPL.), 1-11.

Kaufman, P. E., Nunez, S. C., Geden, C. J., \& Scharf, M. E. (2010). Selection for resistance to imidacloprid in the house fly (Diptera: Muscidae). Journal of Economic Entomology, 103(5). https://doi.org/doi: http://dx.doi.org/10.1603/EC10165

Klauck, V., Pazinato, R., Volpato, A., da Silva dos Santos, D., Santos, R. C. V., Baldissera, M. D., \& da Silva, A. S. (2018). Insecticidal effect of several essential oils against Musca domestica.

Comparative Clinical Pathology, 27(1), 167-172. https://doi.org/10.1007/s00580-017-2572-6

Krisdiyanta, \& Ariyani, S. (2018). Kemampuan Jenis Umpan Lalat dengan Menggunakan Fly Trap di Tempat Pemrosesan Akhir ( TPA ) Sampah Talang Gulo Jambi. Jurnal Bahan Kesehatan Masyarakat, 2(1), 68-73.

Kusariana, N. (2013). Uji Resistensi Tiga Golongan Insektisida Terhadap Tiga Isolat Lalat Rumah Musca domestica (Diptera: Muscidae) di Bogor.

Leke, J. R., Widyastuti, T., Mandey, J. S., Najon, M., \& Laihad, J. (2015). Penggunaan tepung insang cakalang (Katsuwonus pelamis) sebagai pengganti tepung ikan dalam beberapa level pemberian dan metode pengolahan terhadap performans ayam broiler. Seminar Nasional Masyarakat Biodeversity Indonesia, 1(4), 771775. https://doi.org/10.13057/psnmbi/m010416

Ministry of Health Indonesia. (2019). Indonesia Health Profile 2019. In Ministry of Health Indonesia (Vol. 53).

Mosokuli, Y. S. (2001). Lalat Tungau dan Caplak sebagai vektor. Laboratorium Bioaktifvitas dab Biologi Molekuler FMIPA UNIMA.

Nadeak, E. S. M., Rwanda, T., \& Iskandar, I. (2017). Efektifitas Variasi Umpan Dalam Penggunaan Fly Trap Di Tempat Pembuangan Akhir Ganet Kota Tanjungpinang. Jurnal Kesehatan Masyarakat
Andalas, 10(1), 82.

https://doi.org/10.24893/jkma.v10i1.167

Nelson, C. S., Beck, J. N., Wilson, K. A., Pilcher, E. R., Kapahi, P., \& Brem, R. B. (2016). Obesity-related diseases are major contributors to morbidity and mortality in the developed world. Molecular diagnostics and targets of therapies to combat nutritional imbalance are urgently needed in the clinic. Invertebrate animals have been a cornersto. BMC Genomic, 17(1), 867.

Oktavia, D. A., Mangunwidjaja, D., Wibowo, S., \& Sunarti, T. C. (2012). Pengolahan Limbah Cair Perikanan Menggunakan Konsorsium Mikroba Indegenous Proteolitik dan Lipolitik. Agrointek, 6(2), 65-71.

Onyenwe, E., Okore, O, O., Ubiaru, P. C., \& Abel, C. (2016). Housefly-borne Helminth Parasites Of Mouauand Its Public Healt Implication For The University Community. Animal Research International, 13(1), 2352-2358.

Palus, T. S., Sanam, M. U. E., \& Detha, A. I. R. (2016). Identifikasi Salmonella sp. dan Escherichia coli pada lalat di tempat penjualan daging Pasar Naikoten Kota Kupang. J. Veteriner Nusantara, 1(1), 10-13.

Pickering, A. J., Ercumen, A., Arnold, B. F., Kwong, L. H., Parvez, S. M., Alam, M., ... Luby, S. P. (2018). Fecal Indicator Bacteria along Multiple Environmental Transmission Pathways (Water, Hands, Food, Soil, Flies) and Subsequent Child Diarrhea in Rural Bangladesh [Research-article]. Environmental Science \& Technology, 52(14), 7928-7936.

https://doi.org/10.1021/acs.est.8b00928

Putra, F. K. (2018). Efektifitas Atraktan Pada Fly Trap Terhadapjumlah Lalat Rumah (Musca Domestica). Jurnal Media Kesehatan, 6(2), 112116. https://doi.org/10.33088/jmk.v6i2.200

Ristiati, N. P., Suryanti, I. A. P., \& Indrawan, I. M. Y. (2018). Isolasi dan Karakterisasi Bakteri Tanah Pada Tempat Pemrosesan Akhir di Desa Bengkala Kabupaten Buleleng. Wahana Matematika Dan Sains, 12(1), 64-77. Retrieved from

https://ejournal.undiksha.ac.id/index.php/JPM/ar ticle/view/pril2018-6

Saipin, Fadmi, F. R., \& Mauliyana, A. (2019). Efektivitas Variasi Umpan terhadap Penggunaan Perangkap Lalat (Fly Trap) di Pasar Basah Anduonohu Kota Kendari. MIRACLE Journal of Public Health, 2(1), 112-120.

Sanyaolu, A., Okorie, C., Marinkovic, A., Jaferi, U., \& Prakash, S. (2020). Global Epidemiology and 
Management of Acute Diarrhea in Children from Developing Countries. Ann Pediatr Child Health, 8(8), 1205.

Shane, S. M., Montrose, M. S., \& Harrington, K. S. (1985). Transmission of Campylobacter jejuni by the Housefly (Musca domestica). Avian Diseases, 29(2), 384. https://doi.org/10.2307/1590499

Sucipto, D. C. (2011). Vektor Penyakit Tropis (1st ed.). Jakarta: Gosyen Publishing.

Suraini. (2013). Jenis-jenis Lalat(Diptera) dan Bakteri Enterobacteriaceae yang Terdapat di tempat Pembuangan Akhir Sampah (TPA). 53(9), 16891699.

Tanjung, N. (2016). Efektivitas Brbagai Bentuk Fly Trap dan Umpan Dalam Pengendalian Kepadatan Lalat Pada Pembuangan Sampah Jalan Budi Luhur Medan. Jurnal Ilmiah PANNMED, 17(3), 218-221.

Ugboko, H. U., Nwinyi, O. C., Oranusi, S. U., \& Oyewale, J. O. (2020). Childhood diarrhoeal diseases in developing countries. Heliyon, 6(4), e03690. https://doi.org/10.1016/j.heliyon.2020.e03690

UNICEF. (2020). Diarrhoea. Retrieved from UNICEF website: https://data.unicef.org/topic/childhealth/diarrhoeal-disease/

Wahyudi, P., Hadi, U. K., \& Soviana, S. (2015). Keanekaragaman Jenis dan Prevalensi Lalat Pasar Tradisional di Kota Bogor. Jurnal Veteriner, 16(4), 474-482.

Walker, C. L. F., Rudan, I., Liu, L., Nair, H., Theodoratou, E., Bhutta, Z. A., ... Black, R. E.
(2013). Global burden of childhood pneumonia and diarrhoea. The Lancet, 381(9875), 14051416. https://doi.org/10.1016/S01406736(13)60222-6

Wang, L., Wei, B., Chen, Z., Deng, L., Song, L., Wang, S., ... Zhang, Y. (2015). Effect of inoculum and sulfide type on simultaneous hydrogen sulfide removal from biogas and nitrogen removal from swine slurry and microbial mechanism. Applied Microbiology and Biotechnology, 99(24), 1079310803. https://doi.org/10.1007/s00253-0156916-3

Wateraid. (2019). Faeces, Fields, Fingers, Food, Fluids and Flies? Retrieved March 30, 2021, from Https://www.wateraid.org/ website: https://www.wateraid.org/au/articles/faecesfields-fingers-food-fluids-and-flies

Yunianti Lapida. (2016). Uji Efektivitas Ekstrak Daun Sirih Hijau (Piper betle) sebagai Insektisida Alami Terhadap Mortalitas Walang Sangit (Leptocorisa acuta).

Yushananta, P., Ahyanti, M., \& Hasan, A. (2018). Sanitasi Total Berbasis Masyarakat di Desa Muara Putih Kecamatan Natar Kabupaten Pesawaran. Sakai Sambayan Jurnal Pengabdian Kepada Masyarakat, 2(2), 76. https://doi.org/10.23960/jss.v2i2.79

Yushananta, P., \& Usman, S. (2018). The Incidence of Diarrhea in Babies Affected through the Cleanliness of Eating Utensils and Hands. Journal of Medical Science And Clinical Research, 6(9). https://doi.org/10.18535/jmscr/v6i9.137 